\title{
Psychological Suppositions of the Program Implementation for the Personal and Professional Development of the Future Teacher in the Educational Process
}

\author{
Svitlana Bilozerska ${ }^{1},{ }^{*}$ Svitlana Mashchak ${ }^{1}$ \\ ${ }^{I}$ Drohobych Ivan Franko State Pedagogical University, Ukraine \\ *Email: lana_sun@meta.ua
}

\begin{abstract}
The article analyzes the main aspects of the technology of implementation of the program of personal and professional development of the future teacher in the educational process of the pedagogical university. It is stated that personal development and professional development are a prolonged process that requires adequate ways, forms and methods, close cooperation of teachers and students in the implementation of technology of psychological knowledge and psychological support programs for students to master professional competencies. The technologies for the formation of psychological knowledge, the skills of analyzing school pedagogical, educational situations, the ability to model the educational process, taking into account the development situation (physiological, moral, mental, psychological, social, spiritual), leading activities, mental neoplasms of a particular student, educational potential a specific family and the peculiarities of communication with friends, relatives and social environment determine the professional development for the personal growth of the future teacher.
\end{abstract}

Keywords: Professional competence, Program of personal and professional development, Training.

\section{INTRODUCTION}

The problem of a profession choice is especially important among the youth in the contemporary world of technologies. The analysis of applicants admission statistics to higher educational pedagogical institutions of Ukraine shows that the profession of a teacher is chosen by quite a low percentage of young people. The main reason for this is youth stereotyping about this profession, the economic and moral society homogenization by the personality of the teacher. This approach leads to the fact that there exist three types of students in the pedagogical institutions with a subsequent pedagogical orientation. These types are genuine pedagogical, formally pedagogical, and pseudo pedagogical. It is obvious that only the first orientation type is the most favorable for the future profession. Therefore the question arises of how to protect this type among others? What to do with the students of other orientation types for the educational process to be a developing cooperation in the system "student-teacher"? The answer to this question will change the training quality of future teachers.

The scientific problem is that psychological and pedagogical researches do not sufficiently represent the aspect of psychological support for the future teacher's personal and professional development in the pedagogical university educational process. A value attitude towards professional activity can be expected in case if the future profession does not conflict with the existing personal attributes, professional development corresponds to the main value criteria, and the problem of choosing and mastering professional activity is a part of the life purpose implementation. To achieve the declared approach implementation is possible only when the study program content is focused on the development model of a future teacher, addressed to his personality, and does not present an academic science projection. 
The purpose of the article is a theoretical and methodological analysis of the program implementation for the personal and professional development of a future teacher in the educational process of a pedagogical university.

\section{RESEARCH METHODOLOGY}

In the contemporary education system, first of all, it is the classical paradigm of scientific thinking that is presented, and it is focused on the subjective reality of science. In the scope of our research, we are guided by the synergistic paradigm of education, which concentrates on changing the path in the professional training of future specialists, and will create conditions for harmonious personal and professional development and self-development, training and self-training, education and self-education of future teachers.

Under the conditions of educational reforms, a new methodological approach to the process of professional training of a future teacher is required, and the basis of this approach should be the introduction of a personal and professional development program of a future teacher into the educational process. The suggested innovative program makes the learning process mutually educational, interactive, where the student and the teacher become an integral system in which the motivational resources of self-regulation, self-control, and self-organization of future pedagogical activities are promoted. Thus, foreign scientists Glazerman S., Isenberg E., Dolfin S., Bleeker M., Johnson A., marked that the only possible option to fulfill the future teacher personal and professional potential is the possibility of the career growth, which reflects the vertical model of a pedagogical interaction [1]. A dynamic approach to unlocking the personal and professional potential of a future teacher is also analyzed alongside the vertical model [2]. Considering the problem of personal and professional development of a future teacher, Anna I. Klieba, Yuliia O. Bludova, Nataliia A. Galushko focus on the individual educational paths construction to reveal the future teachers' personal and professional development, analyze the problem of mentoring [3].

A Ukrainian scientist M. Savchin places attention on the formation of healthy pedagogical activity in the psychological, mental, moral, physiological, and spiritual dimensions [4]. N. Kolisnechenko emphasizes the importance of professional motivation development, which affects educational achievement indirectly through the productive strategies of the educational environment [5]. N. Mironchuk analyzes the main tasks of professional and personal self-development [6].

Professional development leads to progressive changes in personal new formations of a future teacher as a result of social, psychological, pedagogical impacts, and personal activity. For this reason, professional training should focus on the situation and personal resources, on assisting to make independent decisions, and the development of professional skills and personal abilities.

\section{RESEARCH RESULTS}

148 first-year students of the Drohobych Ivan Franko State Pedagogical University took part in the research. This research stage consisted of the following: firstly, on the basis of particular factors that facilitate the professionalization process to identify the main motives groups for choosing the profession of a teacher. Secondly, to determine the suppositions for the learning process optimization and the improvement of professional training of the future teacher, taking into account personal attributes. The author's questionnaire allowed us to study the features of future profession choice, personal motivation, and pedagogical orientation special aspects. It was important for us to conduct this research with first-year students, due to the reason that the personal and professional development program implementation in the educational process requires psychological support for a certain period of time (semester, academic year).

Researches on the student professional choice motivation, conducted by T. Ivanova, A. Levin [7], evidence that nowadays an increase in the proportion of students desperate in their professional choice can be observed. For this reason, our research will allow revealing the student's attitude to the future professional activity, its strengths and weaknesses in the motivational environment of the educational institution, the psychological and pedagogical suppositions for personal and professional development.

As it can be observed from table 1, 95\% of students marked personal attributes among the most important factors assisting the professional development process. Not least important are the factors based on both external and internal motives - these are academic success and interest in the subject of study - 53\% and 53.5\%. The choice of these factors allows the assertion of students' high level of responsibility for their work results and a sense of duty. That kind of students will be able to reach the professional top levels, they have an acute and deep felt-need for self-improvement.

However, academic success is not always achieved by students' own efforts, but also requires support from teachers, parents and classmates. As it can be observed from table 2, the majority of first-year students place the responsibility for their professional development on other people and circumstances among the factors that interfere with the professionalization process. 
Table 1. Factors assisting the professional development process

\begin{tabular}{|l|l|c|}
\hline \multicolumn{1}{|l|}{$\begin{array}{l}\text { Nem } \\
\text { No. }\end{array}$} & \multicolumn{1}{|c|}{ The list of the factors assisting the professional development process } & $\begin{array}{c}\text { Students, } \\
\text { quantity in \% }\end{array}$ \\
\hline 1. & Personal attributes & 95 \\
\hline 2. & Academic achievements & 53 \\
\hline 3. & Interest in the subject of study & 53,5 \\
\hline 4. & The healthy psychosocial climate in cooperation & 45 \\
\hline 5. & The rational profession choice & 20 \\
\hline 6. & The future profession prestige & 41 \\
\hline 7. & Health condition & 30 \\
\hline 8. & Drive to professional communication & 32 \\
\hline 9. & Confidence in own powers & 28 \\
\hline 10. & Support from relatives and friends & 52 \\
\hline 11. & Desire to improve own professional level & 17 \\
\hline
\end{tabular}

The following factors were marked as the ones interfering with the process of professional development: laziness - 54\%; the unhealthy psychosocial climate in the group - 40\%; the indifference of teachers - 62\%; incomplete teaching methodology $-50 \%$. The existence of such factors can be explained by the pointlessness of the social, professional, personal significance of professionalism as a qualitative characteristic of pedagogical activity.

The obtained answers make it possible to state that almost half of the respondents (47\%) of first-year students are satisfied with their future professional choice and demonstrate positive motivation, $36 \%$ of students are unsure and are not able to ground independently the importance of the choice, and the rest of the students are unhappy with the choice of the profession of a teacher.

It is also necessary to take into account the fact that pseudo-professionalism can also be manifested at the stage of the primary professional development process. The basic reasons for the pseudo-professionalism are the following: the non-correspondence between the individual characteristics of the student's personality and the pedagogical activity requirements, the lack of pedagogical abilities development, insufficient ability force to identify barriers that interfere with the professional growth, the lack of a formed individual educational style and pedagogical activity, the gap between the real professional image and the standard existing in society, a low level of teachers scientific skills. All the mentioned above makes yesterday's applicants focus on situational social values. Only $1 / 4$ part of students chooses the profession of a teacher, guided by reasons that indicate the pedagogical individual orientation.

Taking this into consideration, the pedagogical universities' educational space should be "studentcentered", which will allow the changing of motivation and building of an individual path of personal and professional development. Inside the pedagogical universities, this can be achieved by means of the psychological support of the teaching process, education and development of future teachers with the help of technology resources for the implementation of an

Table 2. Factors interfering with the professional development process

\begin{tabular}{|l|l|c|}
\hline \multicolumn{1}{|l|}{ Item No. } & \multicolumn{1}{|c|}{ Factors interfering with the professional development process } & $\begin{array}{c}\text { Students, } \\
\text { quantity } \%\end{array}$ \\
\hline 1. & Laziness & 64 \\
\hline 2. & Family problems & 38 \\
\hline 3. & Unhealthy psychosocial climate & 40 \\
\hline 4. & Lack of material resources & 58 \\
\hline 5. & Incomplete teaching methodology & 50 \\
\hline 6. & Indifference of teachers & 62 \\
\hline 7. & Unwillingness to work within specialty & 20 \\
\hline
\end{tabular}


individual program of personal and professional development.

\section{RESULTS DISCUSSION}

Independent evaluation of one's own pedagogical potential in future professional activity is provided by forming an individual program of personal and professional development.

The implementation goal of the personal and professional development program is the creation of a fully developed healthy personality of a future teacher, mastering a healthy individual style of educational, pedagogical, educational activities, professional realization growth, professional competencies and personal abilities, the full realization of psychological potential, activation of self-development process (student development as a subject of his own life and work).

When making a program, a student should take into consideration the following parts of personal and professional development: development and health promotion; personal development; mental development; social and professional development, and moral and spiritual development.

As per our observations, a student who makes his own personal and professional development program during the first or second year of study comes against a problem: how to make a program and how to implement it. A student searches ready-to-use stereotyped and one-sizefits-all approaches, counting on the Internet or other students' help. When making a plan for personal growth in the program and seeking the implementation methods of the planned in the moral, spiritual, and social spheres, students are often concerned about the question: how to establish conflict-free communication with parents, why moral, spiritual and social standards often generate internal disharmony and cognitive dissonance.

The monitoring of the maintenance process of the future teacher's personal and professional development indicates that the content personal meaning of psychological disciplines has shifted to the applied field for students. The structure of practical and lecture classes, based on an innovative methodological approach, actualizes the personality structures of the future teachers' consciousness to obtain system psychological knowledge, skills and abilities. [8] 92\% of future teachers are ready to change the process of personal development and professional movement towards future teaching activities [9].

Taking this into consideration, the planning of teacher-student work active modes (analysis of pedagogical situations, creative discussions, psychological problems solving, teacher-student interaction modeling, analysis of school conflict situations, life problems) allows the implementation of both the subject and instrumental contents of the future professional activity. The student-teacher learns both to realize his own authenticity, personal negative and positive individual attributes in the development process of temperament, character, skills, thinking, mnemonic abilities, and develops reflexive abilities and competence in the field of understanding, helping, supporting others. In other words, he fully realizes the necessity to love, to believe, to do good not only for himself but also for future students, parents, teachers, society.

The prolonged implementation of the psychological support program for the professional skills mastering by students requires adequate ways, forms and methods of its fulfillment. And for this reason, the primary task of the future teacher personal development is the creation of the analysis skills of school pedagogical, educational situations and the ability to model the educational process, taking into account the evolving situation (physiological, moral, mental, psychological, social, spiritual), principal activities, new mental formations, the particular family educational potential and features of communication with friends, relatives and social environment. R. Milenkova focuses on the process of the self-education mechanism development as a component of the student's personal and professional growth in the educational process [10].

The settlement of these contradictions in the future teacher professional training should be based on such a methodological approach to the personal and professional skills development, which provides its systematic and prolonged study during the entire period of a student's training at a pedagogical university by implementing the technology of personal and professional development program, training forecasting in the field of education and self-education, development and self-development, early diagnosis of possible negative trends in the formation process of future teachers.

\section{CONCLUSIONS}

Our research shows the importance of the program implementation into the educational process of a pedagogical university, its compilation contributes to personal development, students' understanding of skills and personality categories content, harmonization of the inner world, and acceptance of the problem of personal and professional development and self-development. For many students, the creation of a personal and professional development program, practical classes in psychology gave rise to its practical implementation, pathways choice, fulfillment methods not only for a month or a semester but also for subsequent years of study at a pedagogical university.

The development of the future teacher professional skills is included in the general context of personality 
growth, while the technology modernization and optimization to obtain knowledge in psychology, a creation of the program for the personal and professional students development throughout the years of study at the pedagogical university, professional psychological and pedagogical guidance of the personal and professional development process of the future teacher create all suppositions for the growth of a professionally healthy teacher in the physical, mental, psychological, moral, social and spiritual dimensions.

\section{REFERENCES}

1. S. Glazerman, E. Isenberg, S. Dolfin, M. Bleeker, A. Johnson, M. Grider \& M. Jacobus, Impacts of comprehensive teacher induction: Final results from a randomized controlled study (NCEE 2010-4028), 2010 .

2. M. Snoek, J. Dengerink \& B. Wit, Reframing the teacher profession as a dynamic multifaceted profession: A wider perspective on teacher quality and teacher competence frameworks, European Journal of Education 54 (2019) 413-425. DOI: https://doi.org/10.1111/ejed.12350

3. Anna I. Klieba, Yuliia O. Bludova, Nataliia A. Galushko, Olena H. Pavlova \& Nataliia V. Pylypenko, Construction of an Individual Educational Trajectory as a Way to Reveal the Personal and Professional Potential of a Future Teacher - International Journal of Higher Education VoI, 9. Iss. 7(Special Issue) (2020) 73-84. DOI: https://doi.org/10.5430/ijhe.v9n7p73

4. Osobystisno-profesiynyi rozvytok maybutnyogo pedagoga [Personal and professional development of the future teacher]: monograph, Rev. prof. M.V. Savchina - Drohobych: publishing department of Drohobych Ivan Franko State Pedagogical University, 2014, 331 p.

5. Natalia Yu. Kolesnichenko, Tetiana S. Hladun , Olena S. Diahyleva, Lyubov Y. Hats \& Antonina V. Karnaukhova, Increasing Students' Motivation to Learn at Tertiary Educational Institutions International Journal of Higher Education VoI, 9. Iss. 7(Special Issue) (2020) 166-176 DOI: https://doi.org/10.5430/ijhe.v9n7p166

6. N.M. Mironchuk, Profesiyno-osobystisnyi samorozvytok maybutnyogo pedagoga: sutnisni kharakterystyky ta shlyahy formuvannya [Professional and personal self-development of the future teacher: essential characteristics and ways of formation], Novi tekhnologii navchannya [New technologies of training]: nauk.-metod.zb, Kyiv Iss. 76 (2013) 209-214.
7. T.A. Ivanova, A.Y. Levin, Motivatsiya uchebnoy deyatelnosti studentov, Psihologicheskie mehanizmy regulyatsii povedeniya i optimizatsii trudovoy i uchebnoy deyatelnosti [Motivation of educational activity of students, Psychological mechanisms of regulation of behavior and optimization of labor and educational activity]: Mezhvuz. sb., rev. G.S. Shlyahtina, Gorky: Gorky state university, 1987, pp. 77 - 84.

8. S.I. Bilozerska, Osobysta zrilist yak umova profesiynogo zrostannya maybutnyogo pedagoga [Personal maturity as a condition for professional growth of the future teacher], S.I. Bilozerska, Teoria i praktika suchasnoi psihologii: Zbirnyk naukovyh prats Zaporizhzhia Vol. 2. Iss. 5. (2019) 20-25,

9. S. Maschak, Ovolodinnya studentamy profesiynymy kompetentsiyamy u sferi vyhovannya ta rozvytku shkolyariv zasobamy psyhologii, S. Maschak, Teoria i praktyka psyhologichnogo suprovodu osobystisno-profesiynogo zrostannya maybutnih pedagogiv pry vukladanni psyhologichnyh dystsyplin: monograph, Rev. prof. M.V. Savchina, Drohobych, «Shvydkodruk», 2020, pp. 218-230.

10. R.V. Milenkova, Gotovnist do samoosvity yak komponent osobystisno-profesiynogo rozvytku studentiv ta problemy ii formuvannya [Readiness for self-education as a component of personal and professional development of students and the problems of its formation] [Text], R.V. Milenkova, Teoretychni pytannya nauky, osvity ta vyhovannya nauky: zbirnyk naukovyh statey. Kyiv Iss. 43 (2011) $31-34$. 